\title{
PENGARUH PENDEKATAN KELOMPOK TERHADAP \\ KEBERDAYAAN PEMBUDIDAYA \\ (Kasus di Kabupaten Sleman Provinsi Daerah Istimewa Yogyakarta)
}

Oleh :

Ani Leilani dan Aan Hermawan

Dosen Jurusan Penyuluhan Perikanan Sekolah Tinggi Perikanan

\begin{abstract}
ABSTRAK
Penelitian tentang pengaruh pendekatan kelompok terhadap keberdayaan pembudidaya dilakukan pada Bulan Juli sampai dengan September 2010 di Kabupaten Sleman Provinsi Daerah Istimewa Yogyakarta, dengan jumlah responden 38 orang. Penelitian ini bertujuan : 1) Menentukan distribusi kelompok pembudidaya di Kabupaten Sleman pada sejumlah karakteristik yang diamati; dan 2) Menentukan hubungan antara karakteristik kelompok pembudidaya dan pendekatan kelompok dengan keberdayaan pembudidaya di Kabupaten Sleman. Hasil penelitian menunjukkan bahwa : 1) Kelompok pembudidaya ikan di Kabupaten Sleman dalam menjalankan fungsinya masih dalam kategori sedang. Hal ini menunjukkan fungsi kelompok sebagai wadah belajar mengajar, produksi dan wahana kerjasama belum dapat dijalankan secara optimal. Intensitas kunjungan penyuluh ke lapangan dan kelompok pembudidaya juga belum secara intens dilakukan; 2) Keberdayaan pembudidaya melalui pendekatan kelompok yang ditunjukkan dengan adanya peningkatan pengetahuan, keterampilan dan sikap; Peningkatan produksi; dan Kemandirian pembudidaya dalam pengambilan keputusan termasuk dalam kategori sedang; 3) Karakteristik pembudidaya (umur, pendidikan formal, pendidikan non formal, pekerjaan, luas lahan yang dikelola, pengalaman usaha, tingkat pendapatan, status sosial pembudidaya dan motivasi serta partisipasinya dalam kegiatan penyuluhan) menunjukkan tidak berpengaruh nyata terhadap keberdayaan pembudidaya; 4) Pendekatan kelompok memiliki pengaruh yang sangat nyata terhadap keberdayaan pembudidaya terutama dalam peningkatan pengetahuan keterampilan sikap pembudidaya, peningkatan produksi dan kemandirian pembudidaya dalam pengambilan keputusan.
\end{abstract}

Kata Kunci : Pemberdayaan, pendekatan kelompok, pembudidaya. 
PENDAHULUAN

\section{Latar Belakang}

Perkembangan

pembangunan

Kelautan dan Perikanan dirasakan saat ini belum mampu meningkatkan harkat, martabat dan kesejahteraan pelaku utama/pelaku usaha. Kemungkinan yang menjadi penyebab hal ini adalah ; pertama pembangunan hanya mengutamakan pertumbuhan, mengejar target dan jarang memperhatikan faktor manusia sebagai subjek, dalam prakteknya sering dijumpai martabat manusia menurun dan sering menjadi alat untuk mencapai tujuan ekonomi. Kedua, tidak efisiensinya sistem birokrasi yang dikembangkan oleh pemerintah, golongan yang diuntungkan adalah mereka yang dekat dengan elit kekuasaan atau mereka yang secara sosial ekonomi mampu meraih kesempatan yang ada.

Pembangunan yang selama ini dilaksanakan belum banyak mengubah pelaku utama/pelaku usaha perikanan, salah satu penyebabnya adalah pelaku utama/pelaku usaha kurang diberdayakan, orang miskin akan tetap miskin selama dia tidak berdaya untuk mendayagunakan kemampuannya, untuk mengembangkan kapasitasnya dan berproduktif. Melalui pemberdayaan maka semua potensi yang dimiliki oleh seseorang akan mengalami perubahan selama orang itu mau berubah.
Kehidupan masyarakat tidak terlepas dari kelompok, termasuk kelompok pelaku utama/pelaku usaha bidang kelautan dan perikanan. Oleh karena itu dalam suatu kelompok ada dinamika yang menggerakkan kelompok tersebut yaitu melalui pemberdayaan. Kekuatan atau gerak yang terdapat dalam kelompok menentukan perilaku kelompok dan anggotanya dalam pencapaian tujuan. Kekuatan-kekuatan tersebut menurut Slamet (2004) bersumber dari 9 unsur, yang meliputi: 1) tujuan kelompok, 2) struktur kelompok, 3) fungsi tugas, 4) pembinaan dan pengembangan kelompok, 5) kesatuan kelompok, 6) suasana kelompok, 7) ketegangan kelompok, 8) efektivitas kelompok, dan 9) maksud terselubung.

Kabupaten Sleman merupakan salah satu wilayah yang memiliki potensi pengembangan budidaya perikanan air tawar, beberapa komoditas diantaranya ikan lele, nila, gurame, komoditas tersebut dapat meningkatkan PAD Kabupaten Sleman. Pengelolaan pengembangan budidaya air tawar dilakukan oleh pembudidaya yang tergabung dalam kelompok maupun gabungan kelompok pembudidaya. Tugas seorang penyuluh adalah harus menyesuaikan dengan kondisi kelompok pembudidaya untuk dapat melakukan pemberdayaan sehingga 
mampu mengembangkan kapasitas dan kemandirian pembudidaya.

\section{Masalah Penelitian}

Pemberdayaan telah dilakukan setiap saat dari waktu ke waktu oleh penyuluh, tetapi apakah pemberdayaan yang telah dilakukan mampu mengembangkan kapasitas pembudidaya sesuai dengan kemampuannya. Permasalahan yang spesifik dari penelitian ini adalah :

1. Bagaimana distribusi kelompok pembudidaya dalam upaya meningkatkan kapasitasnya?

2. Sejauhmana pemberdayaan yang dilakukan oleh para penyuluh melalui peranannya sehingga dapat merubah perilaku kelompok pembudidaya?

3. Bagaimana hubungan antara karakteristik kelompok pembudidaya dengan pemberdayaan dengan pendekatan kelompok?

\section{Tujuan Penelitian}

Berdasarkan uraian masalah di atas, penelitian ini bertujuan:

1. Menentukan distribusi kelompok pembudidaya di Kabupaten Sleman pada sejumlah karakteristik yang diamati.

2. Menentukan hubungan antara karakteristik kelompok pembudidaya dan pendekatan kelompok dengan keberdayaan pembudidaya

di

Kabupaten Sleman.

\section{Manfaat Penelitian}

Hasil penelitian diharapkan dapat dijadikan sebagai bahan pertimbangan dalam membuat program penyuluhan dalam rangka pemberdayaan kepada pembudidaya secara efektif dan efisien sekaligus memberikan sumbangan pemikiran bagi penentu kebijaksanaan dalam merumuskan program pengembangan dan pemberdayaan penyuluhan perikanan.

\section{KERANGKA PENELITIAN DAN HIPOTESIS}

\section{Kerangka Penelitian}

Pemberdayaan dilahirkan dari bahasa Inggris, yakni empowerment, yang mempunyai makna dasar "pemberdayaan”, di mana "daya” bermakna kekuatan (power). Bryant \& White (1987) menyatakan pemberdayaan sebagai upaya menumbuhkan kekuasaan dan wewenang yang lebih besar kepada masyarakat miskin. Caranya dengan menciptakan mekanisme dari dalam (build-in) untuk meluruskan keputusan-keputusan alokasi yang adil, yakni dengan menjadikan rakyat mempunyai pengaruh. Sementara Freire (Sutrisno, 1999) menyatakan empowerment bukan sekedar memberikan kesempatan rakyat menggunakan sumber 
daya dan biaya pembangunan saja, tetapi juga upaya untuk mendorong mencari cara menciptakan kebebasan dari struktur yang opresif.

Menurut Padmowihardjo (2005), makna sebenarnya dari pemberdayaan adalah to give official authority or legal power, capacity, to make one able to do something. Dengan demikian pemberdayaan dapat diartikan sebagai suatu proses kapasitas atau pengembangan kapasitas sumberdaya manusia. Dengan kapasitas seseorang akan memiliki kekuatan (daya) atau kewenangan yang diakui secara official atau legal sehingga orang tersebut tidak termarginalisasi, melainkan sadar akan harga dirinya, harkat dan martabatnya.

Konsep lain menyatakan bahwa pemberdayaan mempunyai dua makna, yakni mengembangkan, memandirikan, menswadayakan dan memperkuat posisi tawar menawar masyarakat lapisan bawah terhadap kekuatan-kekuatan penekan di segala bidang dan sektor kehidupan. Makna lainnya adalah melindungi, membela dan berpihak kepada yang lemah, untuk mencegah terjadinya persaingan yang tidak seimbang dan terjadinya eksploitasi terhadap yang lemah (Prijono dan Pranarka, 1996).

Dalam pandangan Pearse dan Stiefel dinyatakan bahwa pemberdayaan mengandung dua kecenderungan, yakni primer dan sekunder. Kecenderungan primer berarti proses pemberdayaan menekankan proses memberikan atau mengalihkan sebagian kekuasaan, kekuatan atau kemampuan kepada masyarakat agar individu menjadi lebih berdaya. Sedangkan kecenderungan sekunder melihat pemberdayaan sebagai proses menstimulasi, mendorong atau memotivasi individu agar mempunyai kemampuan atau keberdayaan untuk menentukan apa yang menjadi pilihannya (Prijono dan Pranarka, 1996).

Foster (1973) menyatakan bahwa kegiatan manusia dalam kelompok social dipengaruhi oleh sistem sosial, budaya dan psikologi kelompok atau masyarakat tempat orang tersebut berada. Sistem sosial mengatur bagaimana hubungan diantara anggota-anggotanya, bagaimana status dan peranan masing-masing anggota, serta hak dan kewajibannya.

Penelitian ini dilandasi oleh adanya pengaruh antar variabel seperti pada Gambar 1 berikut. Gambar 1 menjelaskan bahwa sejumlah pendekatan kelompok pembudidaya dalam hal ini peubah bebas $(\mathrm{X})$ berpengaruh dengan keberdayaan kelompok (peubah terikat Y) 


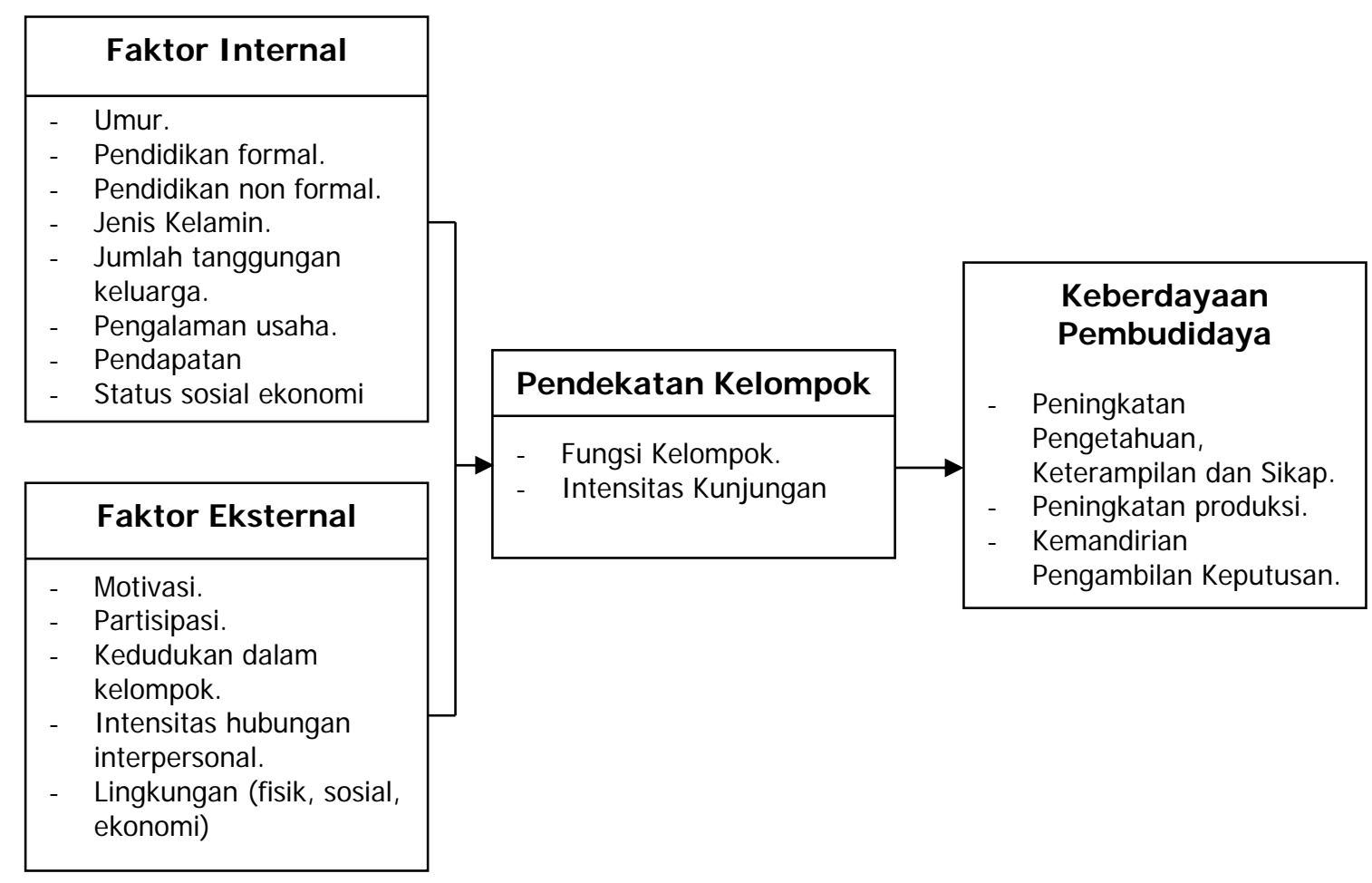

Gambar 1. Diagram Alir Pengaruh Pendekatan Kelompok terhadap Keberdayaan Pembudidaya

\section{Hipotesis}

Berdasarkan kerangka pikir di atas, dapat dirumuskan hipotesis penelitian, yaitu :

1) Karakteristik

pembudidaya

berpengaruh nyata terhadap

peningkatan partisipasi anggota dan

keberdayaannya dalam kelompok;

2) Pendekatan kelompok berpengaruh nyata terhadap keberdayaan pembudidaya dalam melaksanakan usahanya;

\section{METODE PENELITIAN}

\section{Rancangan Penelitian}

Penelitian ini dirancang sebagai penelitian eksplanotoris, yaitu penelitian survei yang bertujuan menjelaskan pengaruh atau mengkaji hubungan antara peubah-peubah penelitian, melalui pengujian hiptoses yang telah dirumuskan sebelumnya.

\section{Lokasi dan Waktu}

Penelitian ini dilaksanakan di Kabupaten Sleman Provinsi Daerah Istimewa Yogyakarta, pada Bulan Juli sampai September 2010. Lokasi penelitian ditentukan secara purposif didasarkan kepada kecamatan yang memiliki potensi pengembangan budidaya ikan air tawar. 
Populasi dan Sampel

Populasi penelitian adalah kelompok pembudidaya ikan air tawar di beberapa kecamatan pada Kabupaten Sleman yang dibina oleh petugas penyuluh perikanan. Menurut data administrasi terdapat 17 kecamatan yang terdapat kelompok pembudidaya dengan jumlah kelompok 358 kelompok.

Sampel diambil secara purposive dari 15 kecamatan terpilih, yaitu Kecamatan Ngaglik (3 kelompok), Kecamatan Seyegan (3 kelompok), Kecamatan Mlati (2 kelompok) Kecamatan Godean (3 kelompok), Kecamatan Kalasan (3 kelompok), Kecamatan Minggir (2 kelompok), Kecamatan Cangkringan (3 kelompok), Kecamatan Gamping (3 kelompok), Kecamatan Prambanan (2 kelompok), Kecamatan Depok (2 kelompok), Kecamatan Berbah (3 kelompok), Kecamatan Tempel (3 kelompok) Kecamatan Moyudan (1 kelompok) Kecamatan Turi (3 kelompok) dan Kecamatan Sleman (2 kelompok) sehingga jumlah sampel 38 orang/kelompok pembudidaya.

\section{Pengumpulan Data}

Pengumpulan data dilakukan secara langsung dengan wawancara, menggunakan seperangkat instrumen berupa kuesioner yang berisi pertanyaan atau pernyataan yang bersifat tertutup (memilih alternatif jawaban yang tersedia). Kuesioner dibuat berdasarkan indikator dan parameter yang telah ditentukan. Kuesioner disusun untuk responden kelompok, dalam hal ini ketua kelompok/pengurus kelompok. Pengumpulan data dilakukan oleh peneliti dan dibantu oleh petugas penyuluh setempat, dengan terlebih dahulu mendapat arahan seperlunya dari peneliti. Untuk data sekunder dikumpulkan dari petugas penyuluh dan laporan-laporan dinas.

\section{Analisis Data}

Data yang terhimpun diolah secara deskriptif untuk mengetahui distribusi kelompok berdasarkan peubah karakteristik pribadinya. Selanjutnya dilakukan pengkategorian sesuai dengan skor yang dihasilkan dari masing-masing hasil pengukuran. Analisis untuk menguji hubungan antar peubah yang diamati dilakukan dengan menggunakan teknik analisis regresi dan korelasional Pearson. Analisis data dilakukan dengan menggunakan piranti program (software) SPSS versi 16.

\section{HASIL DAN PEMBAHASAN}

\section{Distribusi Kelompok Pembudidaya}

Kelompok pembudidaya ikan di Kabupaten Sleman tersebar di 17 
kecamatan dengan jumlah kelompok pada mengalami peningkatan dibandingkan tahun 2009 sejumlah 358 kelompok, tahun sebelumnya yaitu sejumlah 315 dengan rincian; 239 kelompok pemula, 95 kelompok pada tahun $2008 . \quad$ Distribusi kelompok lanjut, 20 kelompok madya dan kelompok pembudidaya di Kabupaten 4 kelompok utama. Jumlah kelompok ini Sleman dapat dilihat pada Tabel 1.

Tabel 1. Distribusi Kelompok Pembudidaya Ikan di Kabupaten Sleman, Tahun 2009.

\begin{tabular}{|c|c|c|c|c|c|c|c|c|}
\hline \multirow{2}{*}{ No } & \multirow{2}{*}{ Kecamatan } & \multicolumn{5}{|c|}{ Jumlah Kelompok } & \multirow{2}{*}{$\begin{array}{l}\text { Jumlah } \\
\text { Anggota }\end{array}$} & \multirow{2}{*}{$\begin{array}{c}\text { Luas } \\
\text { Lahan (m2) }\end{array}$} \\
\hline & & Pernula & Lanjut & Madya & Utama & Jumlah & & \\
\hline $\mathbf{1}$ & Gamping & 15 & 1 & o & o & 16 & 496 & 132.950 \\
\hline 2 & Godean & 33 & 9 & 1 & o & 43 & 1.114 & 187.640 \\
\hline 3 & Moyudan & 12 & 8 & 5 & 1 & 26 & 709 & 188.260 \\
\hline 4 & Minggir & 9 & 6 & 2 & o & 17 & 419 & 347.500 \\
\hline 5 & Seyegan & 22 & 6 & o & o & 28 & 828 & 220.200 \\
\hline 6 & Mlati & 21 & 3 & 1 & o & 25 & 611 & 289.760 \\
\hline 7 & Depok & 14 & 7 & 1 & o & 22 & 791 & 444.500 \\
\hline 8 & Berbah & 10 & 4 & 4 & o & 18 & 467 & 252.770 \\
\hline 9 & Prambanan & 11 & 5 & o & o & 16 & 387 & 146.600 \\
\hline 10 & Kalasan & 5 & 8 & 2 & 1 & 16 & 501 & 456.300 \\
\hline 11 & Ngemplak & 12 & 9 & 2 & 2 & 25 & 764 & 810.600 \\
\hline 12 & Ngaglik & 6 & 5 & o & o & 11 & 216 & 35.400 \\
\hline 13 & Sleman & 16 & 8 & o & o & 24 & 772 & 115.865 \\
\hline 14 & Tempel & 21 & o & o & o & 21 & 548 & 59.030 \\
\hline 15 & Turi & 13 & 5 & 1 & o & 19 & 515 & 98.445 \\
\hline 16 & Pakem & 10 & 5 & o & o & 15 & 346 & 42.500 \\
\hline 17 & Cangkringan & 9 & 6 & 1 & o & 16 & 409 & 138.800 \\
\hline \multicolumn{2}{|c|}{ Jumlah Th. 2009} & 239 & 95 & 20 & 4 & 358 & 9.893 & 3.967 .120 \\
\hline \multicolumn{2}{|c|}{ Jumlah Th. 2008} & 205 & 89 & 17 & 4 & 315 & 8.751 & 3.611 .660 \\
\hline \multicolumn{2}{|c|}{ Naik/ Turun (\%) } & 16,59 & 6,74 & 17,65 & 0,00 & 13,65 & 13,05 & 9,84 \\
\hline
\end{tabular}

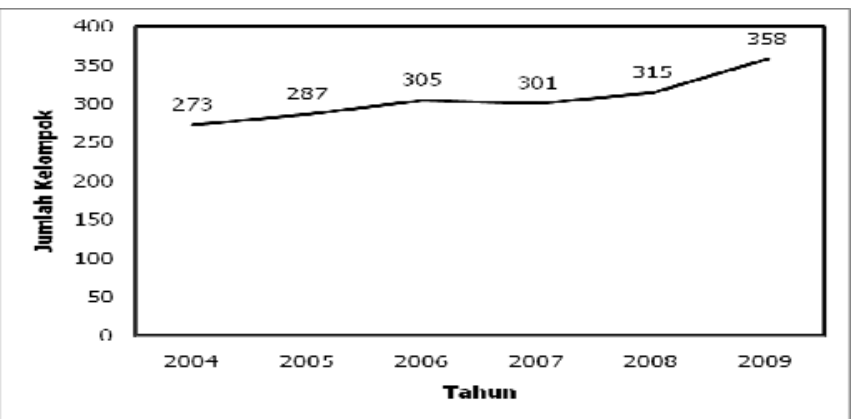

Gambar 2. Perkembangan jumlah kelompok, Tahun 2004 s.d. 2009 


\section{Karakteristik Pembudidaya dalam}

Kelompok

Karakteristik pembudidaya yang keluarga;

9)

Kedudukannya di

masyarakat; 10) Kedudukannya dalam

kelompok; 11) Partisipasinya dalam diamati dalam penelitian ini adalah ; 1) kegiatan penyuluhan; 12) Partisipasi Umur; 2) Pendidikan Formal; 3) dalam kelompok; dan 13) Intensitas Pendidikan Non Formal; 4) Pekerjaan; 5) hubungan dengan pembudidaya lain.

Luas lahan yang Dikelola; 6) Lamanya kegiatan usaha; 7) Besarnya penghasilan per bulan;

8) Jumlah tanggungan
Hasil penelitian tentang distribusi karakteristik pembudidaya dapat dilihat pada tabel 2

Tabel 2. Karakteristik Pembudidaya yang diamati

\begin{tabular}{|c|c|c|c|}
\hline \multirow{2}{*}{ Karakteristik Pembudidaya } & \multirow{2}{*}{ Kategori } & \multicolumn{2}{|c|}{ J umlah } \\
\hline & & $\mathbf{n}$ & $\%$ \\
\hline 1 & 2 & 3 & 4 \\
\hline \multirow[t]{3}{*}{ Umur } & Muda & 9 & 23,68 \\
\hline & Sedang & 17 & 44,74 \\
\hline & Tua & 12 & 31,58 \\
\hline \multirow[t]{3}{*}{ Pendidikan formal } & Rendah & 0 & 0,00 \\
\hline & Sedang & 2 & 5,26 \\
\hline & Tinggi & 36 & 94,74 \\
\hline \multirow[t]{3}{*}{ Pendidikan non formal } & Rendah & 1 & 2,63 \\
\hline & Sedang & 1 & 2,63 \\
\hline & Tinggi & 36 & 94,74 \\
\hline \multirow[t]{3}{*}{ Pekerjaan } & PNS dan lainnya & 5 & 13,16 \\
\hline & Pengolah & 0 & 0,00 \\
\hline & Pembudidaya/pelaku utama & 33 & 86,84 \\
\hline \multirow[t]{3}{*}{ Luas lahan yang dikelola } & Sempit & 34 & 89,47 \\
\hline & Sedang & 4 & 10,53 \\
\hline & Luas & 0 & 0,00 \\
\hline \multirow[t]{3}{*}{ Lama kegiatan usaha } & Sebentar & 0 & 0,00 \\
\hline & Cukup & 16 & 42,11 \\
\hline & Lama & 22 & 57,89 \\
\hline \multirow[t]{3}{*}{ Besar penghasilan } & Kecil & 15 & 39,47 \\
\hline & Sedang & 16 & 42,11 \\
\hline & Besar & 7 & 18,42 \\
\hline \multirow[t]{3}{*}{ Jumlah tanggungan keluarga } & Sedikit & 13 & 34,21 \\
\hline & Sedang & 23 & 60,53 \\
\hline & Banyak & 2 & 5,26 \\
\hline \multirow[t]{3}{*}{ Kedudukan di masyarakat } & Anggota masyarakat & 11 & 28,95 \\
\hline & $\begin{array}{l}\text { Pengurus } \\
\text { organisasi/kelompok }\end{array}$ & 20 & 52,63 \\
\hline & Pemimpin masyarakat & 7 & 18,42 \\
\hline \multirow[t]{3}{*}{ Kedudukan dalam kelompok } & Belum berkelompok & 0 & 0,00 \\
\hline & Anggota kelompok & 5 & 13,16 \\
\hline & Pengurus kelompok & 33 & 86,84 \\
\hline \multirow[t]{3}{*}{ Partisipasi dalam penyuluhan } & Rendah & 18 & 47,37 \\
\hline & Sedang & 17 & 44,74 \\
\hline & Tinggi & 3 & 7,89 \\
\hline Partisipasi dalam kelompok & Rendah & 0 & 0,00 \\
\hline
\end{tabular}




\begin{tabular}{|l|l|c|c|}
\hline & Sedang & 11 & 28,95 \\
\hline \multirow{2}{*}{$\begin{array}{l}\text { Intensitas hubungan } \\
\text { pembudidaya lain }\end{array}$} & Tinggi & 27 & 71,05 \\
\hline & Rendah & 17 & 44,74 \\
\cline { 2 - 4 } & Sedang & 19 & 50,00 \\
\hline & Tinggi & 2 & 5,26 \\
\hline
\end{tabular}

Sumber : Data primer diolah, Tahun 2010.

Tabel 2 memperlihatkan bahwa umur pembudidaya 44,74\% menunjukkan umur sedang yaitu rata-rata berumur produktif, sebagian besar responden menamatkan pendidikan SMU dan perguruan tinggi yaitu 94,74 \% dengan kategori tinggi dan pernah mengikuti pendidikan non formal berupa pelatihan dan magang (94,74\%). Responden sebagian besar memiliki pekerjaan utama sebagai pembudidaya $(86,64 \%)$ dan lama usaha di atas 6 tahun dengan persentase 57,89 \%. Hal ini menunjukkan pengalaman usaha responden di bidang perikanan dinilai cukup tinggi. Meskipun demikian, penghasilan yang diperoleh pembudidaya dari kegiatan usaha perikanannya masih tergolong sedang (antara Rp 1 - 2 juta per bulan) dengan persentase 42,11 \%, yang kemungkinan besar disebabkan karena sebagian besar pembudidaya $(89,47 \%)$ mengelola lahan perikanan relatif sempit/sedikit.

Berdasarkan hasil pengambilan data di lapangan, sebagian besar responden memiliki kedudukan tertentu di masyarakat dan merupakan pengurus kelompok dengan persentase 86,84\%. Perannya pun dalam kegiatan penyuluhan cukup tinggi, aktif membantu dan menjadi penggerak bagi pembudidaya lain, dengan persentase $71,05 \%$. Namun demikian, intensitas hubungan dengan pembudidaya lain masih termasuk dalam kategori sedang dengan persentase $50 \%$.

\section{Pendekatan Kelompok}

Pendekatan kelompok yang diamati dalam penelitian ini mencakup 2 faktor yaitu berjalannya fungsi kelompok dan intensitas kunjungan yang dilakukan penyuluh perikanan lapangan. Variabel yang diamati dalam fungsi kelompok ini antara lain :

1) Berjalannya kelompok sebagai unit produksi;

2) Berfungsinya kelompok dalam memenuhi kebutuhan usaha anggota dalam permodalan, sarana produksi dan pemasaran hasil perikanan;

3) Berfungsinya kelompok dalam memecahkan permasalahan usaha anggotanya;

4) Aktifnya kelompok dalam mengadakan pertemuan dan diskusi;

5) Berfungsinya kelompok sebagai wadah belajar dan bertukar informasi; 
6) Adanya jalinan kerjasama antara kelompok dengan pihak lain

Sedangkan variabel yang diamati dalam intensitas kunjungan antara lain :

1) Adanya kegiatan pembinaan/penyuluhan secara rutin kepada kelompok;

2) Berjalannya fungsi penyuluh dalam memfasilitasi peningkatan teknologi budidaya ikan;

3) Berjalannya fungsi penyuluh dalam memfasilitasi perkembangan dan kemajuan kelompok pembudidaya;
4) Berjalannya fungsi penyuluh dalam menghubungkan kelompok dengan sumber permodalan dan pemasaran;

5) Kemampuan penyuluh dalam menggerakkan kelompok pembudidaya;

6) Kesesuaian kegiatan penyuluhan dengan kebutuhan, permasalahan dan kondisi usaha kelompok;

Distribusi pendekatan kelompok berdasarkan hasil penelitian dapat dilihat pada Tabel 3.

Tabel 3. Pendekatan kelompok yang diamati

\begin{tabular}{|c|l|c|c|}
\hline \multirow{2}{*}{ Pendekatan Kelompok } & \multicolumn{2}{|c|}{ Kategori } & \multicolumn{2}{c|}{ J umlah } \\
\cline { 2 - 4 } & \multicolumn{1}{|c|}{$\mathbf{2}$} & $\mathbf{3}$ & $\mathbf{4}$ \\
\hline \multicolumn{1}{|c}{} & & 0 & 0,00 \\
\hline Fungsi Kelompok & Rendah & 28 & 73,68 \\
\hline & Sedang & 10 & 26,32 \\
\hline Intensitas Kunjungan & Tinggi & 3 & 7,89 \\
\hline & Rendah & 26 & 68,42 \\
\hline & Sedang & 9 & 23,68 \\
\hline
\end{tabular}

Tabel 3 memperlihatkan bahwa fungsi kelompok belum dapat berjalan secara optimal. Sebagian besar responden menyatakan bahwa kelompok pembudidaya ikan di Kabupaten Sleman dalam menjalankan fungsinya masih dalam kategori sedang dengan persentase 73,68\%. Kelompok tergolong aktif mengadakan pertemuan dan berdiskusi dengan anggota kelompoknya, serta dinilai cukup berfungsi dalam menjalankan peranannya sebagai unit produksi, memenuhi kebutuhan anggota dalam permodalan, sarana produksi dan pemasaran, serta menjalin kerjasama dengan pihak lain.

Intensitas kunjungan penyuluh ke lapangan dan kelompok pembudidaya juga masih dalam kategori sedang dengan persentase 68,42 \%. Pembinaan secara berkala dan pertemuan rutin telah dilakukan oleh penyuluh dengan kelompok, serta peran penyuluh sebagai fasilitator dan mediator kelompok cukup dijalankan dengan baik. 
Keberdayaan Pembudidaya

Salah satu indikator dari keberdayaan masyarakat adalah kemampuan dan kebebasan untuk membuat pilihan yang terbaik dalam menentukan atau memperbaiki kehidupannya. Konsep pemberdayaan merupakan hasil dari proses interaksi di tingkat ideologis dan praktis. Pada tingkat ideologis, pemberdayaan merupakan hasil interaksi antara konsep top-down dan bottom-up, antara growth strategy dan people centered strategy. Sedangkan di tingkat praktis, proses interaksi terjadi melalui pertarungan antar ruang otonomi. Maka, konsep pemberdayaan mencakup pengertian pembangunan masyarakat (community development) dan pembangunan yang bertumpu pada masyarakat (community based development). Community development adalah suatu proses yang menyangkut usaha masyarakat dengan pihak lain (di luar sistem sosialnya) untuk menjadikan sistem masyarakat sebagai suatu pola dan tatanan kehidupan yang lebih baik, mengembangkan dan meningkatkan kemandirian dan kepedulian masyarakat dalam memahami dan mengatasi masalah dalam kehidupannya, mengembangkan fasilitas dan teknologi sebagai langkah meningkatkan daya inisiatif, pelayanan masyarakat dan sebagainya. Secara filosofis, community development mengandung makna membantu masyarakat agar bisa menolong diri sendiri', yang berarti bahwa substansi utama dalam aktivitas pembangunan masyarakat adalah masyarakat itu sendiri.

Dalam penelitian ini, keberdayaan pembudidaya melalui pendekatan kelompok diantaranya dilihat dari 3 aspek, yaitu ; 1) Peningkatan pengetahuan, keterampilan dan sikap pembudidaya; 2) Peningkatan produksi usaha perikanan; dan 3) Kemandirian pembudidaya dalam pengambilan keputusan. Hasil penelitian tentang keberdayaan pembudidaya dapat dilihat pada Tabel 4.

Tabel 4. Keberdayaan pembudidaya yang diamati

\begin{tabular}{|c|l|c|c|}
\hline \multirow{2}{*}{ Keberdayaan Pembudidaya } & \multirow{2}{*}{ Kategori } & \multicolumn{2}{c|}{ Jumlah } \\
\cline { 3 - 4 } & & $\mathbf{n}$ & $\mathbf{4}$ \\
\hline $\mathbf{1}$ & $\mathbf{2}$ & $\mathbf{3}$ & $\mathbf{4}$ \\
\hline Peningkatan pengetahuan, keterampilan dan sikap & Rendah & 1 & 2,63 \\
\hline & Sedang & 28 & 73,68 \\
\hline Peningkatan produksi & Tinggi & 9 & 23,68 \\
\hline & Rendah & 8 & 21,05 \\
\hline Kemandirian pengambilan keputusan & Sedang & 23 & 60,53 \\
\hline & Tinggi & 7 & 18,42 \\
\hline & Rendah & 7 & 18,42 \\
\hline & Sedang & 26 & 68,42 \\
\hline & Tinggi & 5 & 13,16 \\
\hline
\end{tabular}


Tabel 4 memperlihatkan bahwa melalui pendekatan kelompok, keberdayaan pembudidaya masuk dalam kategori sedang dengan persentase masing-masing; 1) Peningkatan pengetahuan, keterampilan dan sikap 73,68\% ; 2) Peningkatan produksi 60,53\%; dan 3) Kemandirian pembudidaya dalan pengambilan keputusan 68,42\%.

Hubungan Karakteristik Pembudidaya dan Pendekatan Kelompok dengan Keberdayaan Pembudidaya

Faktor internal/pribadi individu merupakan ciri-ciri yang dimiliki oleh seseorang yang berhubungan dengan semua aspek kehidupan dan lingkungannya. Karakteristik tersebut terbentuk oleh faktor-faktor biologis dan sosiopsikologis. Karakteristik pribadi merupakan salah satu faktor yang penting untuk diketahui seperti perilaku yang ditunjukkan (Sampson dalam Rakhmat 2001).

$$
\text { Menurut Rogers (1969) dan }
$$

Salkind (1985), pemberdayaan masyarakat tidak bisa terlepas dari faktor internal dan eksternal. Faktor internal individu antara lain: umur, pendidikan, jenis kelamin, jumlah tanggungan keluarga, status sosial ekonomi, dan pengalaman masa lalu. Faktor eksternal yang esensial antara lain: peran penyuluh (fasilitator, motivator, katalisator, pendidik, pelatih), lingkungan (fisik, sosial ekonomi), dan ketersediaan dana/modal usaha.

Hasil penelitian menunjukkan bahwa sebagian besar karakteristik pembudidaya yaitu ; umur, pendidikan formal, pendidikan non formal, pekerjaan, luas lahan yang dikelola, pengalaman usaha, tingkat pendapatan, status sosial pembudidaya dan motivasi serta partisipasinya dalam kegiatan penyuluhan menunjukkan tidak berhubungan nyata. Hanya beberapa karakteristik yang menunjukkan hubungan sangat nyata yaitu pendidikan non formal dengan kemandirian dalam pengambilan keputusan, peningkatan produksi dengan lama lama kegiatan usaha, tingkat penghasilan dan intensitas hubungan dengan pembudidaya lain. Hal ini menunjukkan bahwa berdasarkan penelitian, karakteristik internal dan eksternal pembudidaya tidak memberikan pengaruh terhadap keberdayaan pembudidaya, bertolak belakang dengan pernyataan Rogers (1969) dan Salkind (1985). Hubungan antara karakteristik pembudidaya dengan keberdayaannya dapat dilihat pada Tabel 5. 
Tabel 5. Hubungan antara karakteristik dengan keberdayaan pembudidaya.

\begin{tabular}{|l|c|c|c|}
\hline \multirow{2}{*}{$\begin{array}{c}\text { Karakteristik } \\
\text { Pembudidaya }\end{array}$} & \multicolumn{2}{c|}{ Keberdayaan Pembudidaya } \\
\cline { 2 - 4 } \multicolumn{1}{|c|}{$\mathbf{1}$} & Peningkatan PKS & $\begin{array}{c}\text { Peningkatan } \\
\text { Produksi }\end{array}$ & $\begin{array}{c}\text { Kemandirian } \\
\text { pengambilan keputusan }\end{array}$ \\
\hline Umur & $-0,48$ & $-0,052$ & $\mathbf{4}$ \\
\hline Pendidikan formal & 0,106 & $-0,010$ & $-0,117$ \\
\hline Pendidikan non formal & $-0,217$ & $-0,128$ & $-0,420 * *$ \\
\hline Pekerjaan & 0,009 & 0,232 & $-0,37$ \\
\hline Luas lahan yang dikelola & 0,29 & 0,151 & 0,186 \\
\hline Lama kegiatan usaha & 0,156 & $0,474^{* *}$ & 0,110 \\
\hline Besar penghasilan & $0,360 *$ & $0,447 * *$ & $-0,295$ \\
\hline $\begin{array}{l}\text { Jumlah tanggungan } \\
\text { keluarga }\end{array}$ & $-0,170$ & 0,204 & 0,055 \\
\hline Kedudukan di masyarakat & 0,070 & 0,117 & $-0,176$ \\
\hline $\begin{array}{l}\text { Kedudukan dalam } \\
\text { kelompok }\end{array}$ & $-0,158$ & 0,108 & 0,090 \\
\hline $\begin{array}{l}\text { Partisipasi dalam } \\
\text { penyuluhan }\end{array}$ & 0,103 & $0,373^{*}$ & 0,044 \\
\hline Partisipasi dalam kelompok & 0,039 & 0,251 & 0,177 \\
\hline $\begin{array}{l}\text { Intensitas hubungan } \\
\text { dengan pembudidaya lain }\end{array}$ & 0,207 & $0,472^{* *}$ & \\
\hline
\end{tabular}

Sumber : Data primer diolah, Tahun 2010.

Keterangan $\quad: *$. Korelasi signifikan pada taraf nyata 0,05

**. Korelasi signifikan pada taraf nyata 0,01

Berbeda dengan karakteristik pengambilan keputusan. Begitu pula pembudidaya, pendekatan kelompok intensitas kunjungan penyuluh perikanan ternyata memiliki pengaruh yang sangat kepada kelompok pembudidaya nyata terhadap keberdayaan pembudidaya. berpengaruh sangat nyata terhadap Tabel 6 menunjukkan bahwa kelompok peningkatan keberdayaan pembudidaya. dapat berfungsi dengan baik dalam Hal ini menunjukkan bahwa keberadaan peningkatan pengetahuan keterampilan kelompok memiliki peranan dan manfaat sikap pembudidaya, peningkatan produksi yang sangat baik bagi pembudidaya dan kemandirian pembudidaya dalam

Tabel 6. Hubungan antara pendekatan kelompok dengan Keberdayaan pembudidaya.

\begin{tabular}{|c|c|c|c|}
\hline \multirow{2}{*}{$\begin{array}{c}\text { Karakteristik } \\
\text { Pembudidaya }\end{array}$} & \multicolumn{3}{|c|}{ Keberdayaan Pembudidaya } \\
\cline { 2 - 4 } & Peningkatan PKS & $\begin{array}{c}\text { Peningkatan } \\
\text { Produksi }\end{array}$ & $\begin{array}{c}\text { Kemandirian } \\
\text { pengambilan keputusan }\end{array}$ \\
\hline $\mathbf{1}$ & $\mathbf{2}$ & $\mathbf{3}$ & $\mathbf{4}$ \\
\hline Fungsi kelompok & $0,625^{* *}$ & $0,501^{* *}$ & $0,483^{* *}$ \\
\hline Intensitas kunjungan & $0,598^{* *}$ & $0,556^{* *}$ & $0,376^{* *}$ \\
\hline
\end{tabular}

Sumber : Data primer diolah, Tahun 2010.

Keterangan $\quad: *$. Korelasi signifikan pada taraf nyata 0,05

**. Korelasi signifikan pada taraf nyata 0,01

Berperannya pendekatan adanya interaksi yang terus menerus kelompok dalam pemberdayaan antara anggota kelompok dengan pembudidaya dimungkinkan karena stakeholders terkait, termasuk penyuluh 
perikanan sebagai ujung tombak pemberdayaan masyarakat di lapangan. Hal ini sesuai dengan pendapat Slamet (2004), bahwa dalam kelompok terdapat saling ketergantungan antara individu; partisipasi yang terus menerus dari individu; mandiri; ciri selektif; dan keragaman yang terbatas. Kelompok dapat dipandang sebagai suatu sistem sosial. Namun yang paling penting dan perlu dibayangkan adalah antar orangorang itu ada interaksi. Interaksi dapat diinterpretasikan sebagai kerjasama, tolong menolong, atau saling bersaing, permusuhan atau dalam persahabatan. Interaksi ini terwujud dalam bentuk perilaku dengan pola yang sedikit banyak teratur dan sistematis.

\section{KESIMPULAN DAN SARAN}

\section{Kesimpulan}

Berdasarkan pembahasan hasil penelitian yang telah dilakukan, dapat disimpulkan sebagai berikut :

1) Kelompok pembudidaya ikan di Kabupaten Sleman dalam menjalankan fungsinya masih dalam kategori sedang (73,68\%).

Intensitas kunjungan penyuluh ke lapangan dan kelompok pembudidaya juga masih dalam kategori sedang (68,42 \%).

2) Keberdayaan pembudidaya melalui pendekatan kelompok termasuk dalam kategori sedang dengan persentase masing-masing; Peningkatan pengetahuan, keterampilan dan sikap (73,68\%) ; Peningkatan produksi (60,53\%); dan Kemandirian pembudidaya dalam pengambilan keputusan (68,42\%).

3) Karakteristik pembudidaya yaitu ; umur, pendidikan formal, pendidikan non formal, pekerjaan, $\begin{array}{lrr}\text { luas lahan yang } & \text { dikelola, } \\ \text { pengalaman } & \text { usaha, } & \text { tingkat } \\ \text { pendapatan, } & \text { status } & \text { sosial }\end{array}$ pembudidaya dan motivasi serta partisipasinya dalam kegiatan penyuluhan menunjukkan tidak berpengaruh nyata terhadap keberdayaan pembudidaya.

4) Pendekatan kelompok memiliki pengaruh yang sangat nyata terhadap keberdayaan pembudidaya terutama dalam peningkatan pengetahuan keterampilan sikap pembudidaya, peningkatan produksi dan kemandirian pembudidaya dalam pengambilan keputusan.

\section{Saran}

Berdasarkan hasil penelitian, beberapa hal yang dapat disarankan :

1) Perlu dilakukan penelitian serupa dengan responden yang lebih banyak terhadap program-program yang dapat meningkatkan kapasitas pelaku utama dan pelaku usaha perikanan;

2) Perlu dirumuskan batasan-batasan pendekatan kelompok maupun kegiatan pemberdayaan dalam melakukan suatu kegiatan penyuluhan yang bersifat rutin maupun program;

3) Perlu adanya peningkatan kualitas kelompok, penyuluh dan pembudidaya melalui pelatihan maupun pendampingan secara rutin sehingga dapat memerankan fungsinya dalam membina anggota secara maksimal.

\section{DAFTAR PUSTAKA}

Anonim. 2010. Profil Perikanan Sleman Tahun 2009. Dinas Pertanian, Perikanan dan Kehutanan Sleman, Bidang Perikanan. Sleman. 
Mardikanto. $1993 . \quad$ Penyuluhan Pembangunan Pertanian. Universitas Sebelas Maret Press. Surakarta.

Prijono dan Pranarka. 1996. Pemberdayaan : Konsep dan Kebijakan. Makalah pada Pertemuan Tim Teknis Proyek Penyuluhan Pertanian. Bogor.

Rakhmat, J. 2001. Psikologi Komunikasi. Remaja Rosdakarya. Bandung.

Rogers, Everett M. 1995. Difussion of Inovations (4-ed). The Free Press. New York.

Salkind, NJ. 1985. Theories of Human Development. John Wiley and Sons, New York Chichester Brisbane Toronto. Singapore.

Slamet, M. 2003. Membentuk Pola Perilaku Manusia Pembangunan. IPB Press. Bogor.
Slamet, M. 2004. Kelompok, Organisasi dan Kepemimpinan. Program Studi Penyuluhan Pembangunan. Institut Pertanian Bogor.

Siegel, S. 1990. Statistik Non Parametrik untuk I/mu-ilmu Sosial. Gramedia Pustaka Utama. Jakarta.

Van den Ban dan Hawkins. 1990. Penyuluhan Pertanian. Kanisius. Yogyakarta. 